\title{
Thomas Hobbes: Liberal illiberal
}

\author{
Master-Mind Lecture \\ read 15 October 2014
}

\section{NOEL MALCOLM}

Fellow of the British Academy

Abstract: Thomas Hobbes (1588-1679) has often been regarded as a very illiberal thinker - a defender of 'despotism' and an advocate of the principle that 'might is right'. While those accusations are false, it is true that there are distinctly illiberal elements in his thinking. These include absolutism, authoritarianism, anti-constitutionalism and a hostility to democracy. Yet his political theory also contains some of the most important building-blocks of modern liberal thinking about the state and its citizens: the crucial role of consent; natural rights; egalitarianism; the idea of the state as a device to protect people against oppressors; the homogeneity of legal authority within the state; the concept of the state as a public realm; and the idea that the sovereign acts publicly-above all, through law. (These last three points are preconditions of a Rechtsstaat.) And whilst Hobbes denies that people are ruled by a constitution, his theory does acknowledge the need for rule through a constitution.

Keywords: Hobbes; absolutism; consent; egalitarianism; public realm; Rechtsstaat; constitution.

Thomas Hobbes was never a philosopher for the bien pensants. In the period between the publication of his most famous work, Leviathan, in 1651 and his death in 1679 he was the target of frequent attacks by academics, Anglican priests, bishops, and even a former Lord Chancellor. Some of the hostility was odium theologicum, and there were indeed good reasons why readers should take offence at Hobbes's arguments about Christianity and the nature of the Church (an aspect of his work which, for the purposes of this lecture, must be almost entirely left aside). But there were also many accusations against his moral and political theory. Some denounced him as a moral relativist or nihilist who denied the existence of any objective moral values. Many reproached him for believing that 'might is right', substituting brute force for all the 
traditional justifications of political rule, and thus defending the power of tyrants. Yet several critics, starting from the same interpretation, argued that Leviathan was a 'rebel's catechism', since it implied that any rebels who succeeded in raising a greater force than the sovereign, and using it successfully, would thereby automatically gain the right to rule.

Each of these charges was quite false. Hobbes took great pains to demonstrate the existence of the 'Laws of Nature', a set of moral rules that applied to all human beings. He argued explicitly that right is conferred on rulers not by might, but by the consent of the ruled. And he pointed out that that principle applied in just the same way to successful rebels - to whose actions he was generally and vociferously opposed.

Nevertheless, some versions of these accusations linger on in the modern literature. Sheldon Wolin, a distinguished modern American historian of political thought, once wrote that Hobbes's theory was designed to promote a 'culture of despotism': he was, Wolin believed, 'the first modern in whom a despotic mentality was at work.' Other modern critics have added further accusations to the charge-sheet. According to Hannah Arendt, Hobbes was a progenitor of imperialism and totalitarianism; and many writers on international relations (including E. H. Carr and Hans Morgenthau) have portrayed him as promoting or defending wars of aggression. ${ }^{2}$ That last charge is demonstrably false: in several of his works Hobbes went out of his way to condemn military adventurism and all wars conducted for the sake of glory, enrichment or dominion. As he put it in his Dialogue ... of the Common Laws, 'The subjects of those Kings who affect the Glory, and imitate the Actions of Alexander the Great, have not always the most comfortable lives, nor do such Kings usually very long enjoy their Conquests. ${ }^{3}$ The phrase 'comfortable lives' is expressive of a genuinely Hobbesian outlook: in his theory, the role of the state is to provide a framework of security within which individual citizens can seek the satisfaction of whatever goals they may have. The power of the Hobbesian state may be total, in the sense that there are no areas of temporal life in which the state cannot exercise its power (when it perceives the need to do so). But Hobbes provides no argument for using that power in a totalitarian way - that is, for enlisting every aspect of the citizens' lives in an overarching political project.

\footnotetext{
${ }^{1}$ Wolin (1990: 19). Wolin also complained that 'Hobbes was not trying to persuade his readers but to compel them. The logical structure of his argument is a sequence of stark compulsions.' On such grounds, any philosopher who constructs a cogent argument might be accused of despotic tendencies.

${ }^{2}$ Arendt (1973: 142-7); Carr (1939: 144); Morgenthau (1955: 52). On Arendt's larger argument about Hobbes and totalitarianism see Degryse (2008).

${ }^{3}$ Hobbes (2005: 16); cf. Hobbes 1889: II.ix.9, 184; Hobbes 1983: XIII.14; Hobbes 2012: 174 / ii, 518). (Note: references to this edition, cited hereafter just as Leviathan, are given in a double format, with first the page number of the 1651 edition of the English text (which is presented within the text of this edition, and given in most other modern editions), and then the volume and page number of Hobbes 2012. The former element is omitted when only the Latin text is cited.)
} 
When such dramatic but false accusations have been cast aside, however, it is still possible to say that Hobbes's political theory contains some genuinely illiberal components. I shall sketch some of these briefly, before turning to those countervailing liberal elements that are also present; and, as I discuss these two sides of Hobbes's thought, I shall try to show that they represent not an irreconcilable clash of opinions in his mind, but a nexus of interrelated positions. In some ways, it is the interconnectedness of his liberal and illiberal arguments - as, for example, in the case of what I describe below as his 'authoritarian egalitarianism' - that is the most intriguing thing about his whole pattern of thought. This being so, it may be an oversimplification to classify him just as an illiberal who also has some liberal ideas, or as a liberal who has some illiberal ones (though the title of this lecture does make a definite choice between those two - partly in the interests of simplicity, and partly for broader historical reasons).

Several of these liberal and illiberal elements in Hobbes's thinking constitute large topics in themselves, so I have to adopt a broad-brush approach. This also involves taking the terms 'illiberal' and 'liberal' in the most general normative senses in which they are used in ordinary modern English, without descending to the many definitional (and, indeed, historical) problems that may lurk below the surface. The 'illiberal' elements are, at least, easily recognised as such: absolutism, authoritarianism, anti-constitutionalism, and hostility to democracy; and this helps to set the frame for a non-technical use of the term 'liberal' to characterise those political tendencies that run in the opposite direction. When I refer to 'proto-liberal' aspects of Hobbes's thought, I mean something like precursor elements or potential ingredients of modern liberal thinking. I am not trying to align my account with a teleological story in which early modern thinkers, including Hobbes, are necessarily evolving towards modern liberal ideas. Of course, we must see Hobbes as Hobbes, not as a step on the way to something that is not Hobbes. Yet at the same time this does not mean that there are no valid connections to be made with later developments, given that the later thinkers did read both the works of Hobbes himself, and those of other authors who had been influenced by him.

One other general point needs to be made here. It is almost inevitable that, when we admire a thinker, we are inclined to find in his or her work those ideas and values that we also regard as admirable. So there is always the danger of going back into the past and making people in our own image-making them nice. (The example of Walter Kaufman's interpretation of Nietzsche springs to mind.) ${ }^{4}$ There is, I think, no one special method for avoiding this danger; all we have are the normal canons of historical interpretation that govern all our attempts to make sense of the arguments of past thinkers.

\footnotetext{
${ }^{4}$ Kaufman (1950).
} 
I begin with some of the main areas in which Hobbes's attitudes and principles can reasonably be called illiberal.

\begin{abstract}
Absolutism
Hobbes uses the term 'absolute' repeatedly. He describes a king who holds full monarchical power as 'Soveraign absolute'. ${ }^{5}$ Indeed, any sovereign must be absolute, 'or else there is no Soveraignty at all' ${ }^{6}$ 'Power Unlimited, is absolute Soveraignty. And the Soveraign, in every Commonwealth, is the absolute Representative of all the subjects." It is important, when reading such phrases, to note that the term 'absolute' had different connotations in 17th-century English from those it bears today; early modern writers were much more conscious of the derivation of the word from the Latin 'absolutus'. This is a participle of 'absolvo', the verb meaning to free, release, acquit or finish; so the two main senses of 'absolute' in the early modern period, were 'unrestricted, unconditional', and 'complete, not lacking anything'. In political language, the former sense prevailed: 'absolute' power was power (here meaning authority) which was unconstrained, not subject to any higher human power. In 17th-century discourse, the term was used to refer to kingly rule that was bound neither by a higher human authority (such as the Holy Roman Emperor) nor by a body of rules or institutions in the king's own state that could dictate how the kingly authority was to be exercised. In that sense, Hobbes was an 'absolutist' of the most unambiguous kind. And the corollary to this position was his belief that the obedience of the subjects must be 'simple' - meaning that it was unqualified by consideration of any other human rules or institutions. ${ }^{8}$ This did not exclude the possibility of some justified disobedience or resistance, but it limited it to very specific conditions, and ruled out the idea that such disobedience could be ordered by any human authority within the state. ${ }^{9}$
\end{abstract}

\title{
Authoritarianism
}

One of Hobbes's central claims is that political society depends on human authority. Government cannot avoid being arbitrary: that is, subject to the 'arbitrium' or

\footnotetext{
${ }^{5}$ Leviathan, 98 / ii, 296.

${ }^{6}$ Ibid., 105 / ii, 314.

${ }^{7}$ Ibid., 115 / ii, 350 .

${ }^{8}$ Ibid., 106 / ii, 318; 186 / ii, 554.

${ }^{9}$ On the complex issue of justified disobedience in Hobbes's theory, see Mayer-Tasch (1965); Sreedhar (2010).
} 
decision-making of human beings. Discussing the way in which people denounce their governments when they are displeased by their actions - when they dismiss monarchy as 'tyranny', aristocracy as 'oligarchy', and democracy as 'anarchy'-Hobbes insists that decision-making is essential to government:

And that which offendeth the People, is no other thing, but that they are governed, not as every one of them would himselfe, but as the Publique Representant, be it one Man, or an Assembly of men thinks fit; that is, by an Arbitrary government: for which they give evill names to their Superiors; never knowing (till perhaps a little after a Civill warre) that without such Arbitrary government, such Warre must be perpetuall. ${ }^{10}$

The argument is not that all government is or should be purely arbitrary; as we shall see, there is a great emphasis on the importance of civil laws in Hobbes's theory. But it is fundamental to his concept of a law that it expresses a command: he defines law as 'the Commandment of that Man, or Assembly, to whom we have given Soveraign Authority, to make such Rules for the direction of our actions, as hee shall think fit; and to punish us, when we doe any thing contrary to the same'. ${ }^{11}$ Thus the law declares the will of the legislator; and, in Hobbes's mature theory of authorisation, the legislator's authority is itself derived from the will of each and every subject. The implicit contrast, throughout this argument, is between will and reason. Good 'counsel' or advice makes use of reason to discern what is true and recommend what is just, but neither truth nor justice turns a precept into a law; if they did, all obedience would be conditional, and all authority would be provisional, capable of being superseded at any time by a new source of greater wisdom. As Hobbes puts it in the Latin Leviathan: 'The interpretation of the laws of nature, when a state has been set up, depends not on teachers and writers of moral philosophy, but on the authority of the state. The teachings may indeed be true; but law is made by authority, not by truth. ${ }^{12}$

\section{Anti-constitutionalism}

Leviathan, written at the end of a civil war in which Hobbes had been firmly on the royalist side, contains some fierce denunciations of the idea of 'mixed monarchy'. This was a concept which both sides had made use of; their claim, in modern terms, was that England was a constitutional monarchy, with certain powers reserved for the king,

\footnotetext{
${ }^{10}$ Leviathan, 377 / iii, 1094.

${ }^{11}$ Ibid., 284 / iii, 820.

${ }^{12}$ Ibid., ii, 431: 'In Civitate constituta, Legum Naturae Interpretatio non à Doctoribus \& Scriptoribus Moralis Philosophiae dependet, sed ab Authoritate Civitatis. Doctrinae quidem verae esse possunt; sed Authoritas non Veritas facit Legem.'
} 
and other powers held by aristocratic and democratic elements in the constitution. (At the beginning of the conflict, each side had accused the other of making demands or taking actions that would break the fine balance of this system. ${ }^{13}$ In chapter 29 of Leviathan Hobbes ridicules the idea that, whereas the right to make war or peace is held by the king, the right to tax belongs to the House of Commons, and the right to legislate is in king, House of Commons, and House of Lords combined. 'For although few perceive, that such government, is not government, but division of the Commonwealth into three Factions, and call it mixt Monarchy; yet the truth is, that it is not one independent Common-wealth, but three independent Factions. ${ }^{14}$ Hobbes is no less scathing about the idea that a genuine monarchy can exist while being 'limited' by other elements in the constitution of the state: if a so-called king ever operated under such terms, he writes, 'The Soveraignty ... was alwaies in that Assembly which had the right to Limit him; and by consequence the government not Monarchy, but either Democracy or Aristocracy. ${ }^{15}$ Likewise, in an elective monarchy, the electoral body will always be the real sovereign, with the king functioning merely as its minister. ${ }^{16}$ In all these cases, Hobbes is wielding an analytic argument. His point is that in any genuine political system, however constitutionalist it may seem (insofar as the executive authority is limited by some sort of constitutional law), correct analysis can always identify the real sovereign: the person or people who will interpret and enforce that law. And, Hobbes maintains, if there are no such people, it is not a genuine political system, but a recipe for division and chaos.

This leads me to a fourth illiberal theme:

\section{Hostility to democracy}

Hobbes believed that such analysis would identify the sovereign as consisting of one of the three traditional forms: the one (monarchy), the few (aristocracy) or the many (democracy). Clearly, then, he did accept that democracy was a valid type of sovereign rule. Nevertheless, he argued strongly for the superiority of monarchy over the other two forms. His greatest concern was with the psychological and political dynamics of assemblies, where, he feared, the individual members would always tend to act on their private interest, and to combine with those who had related interests to form factions. Democracy, he argued, would become in effect 'an aristocracy of orators, interrupted sometimes with the temporary monarchy of one orator'. ${ }^{17}$ Hobbes

${ }^{13}$ On this debate see Mendle (1985).

${ }^{14}$ Leviathan, 172 / ii, 512.

${ }^{15}$ Ibid., 98-9 / ii, 296.

${ }^{16}$ Ibid., 98 / ii, 296.

${ }^{17}$ Hobbes, 1889, II.ii.5, 120-1. For a searching study of Hobbes's negative attitude to democracy see Hoekstra (2006). 
repeated this point, together with other criticisms of democracy, in chapter 10 of $D e$ cive; in the Preface to the second edition of that work he admitted, however, that the superiority of monarchy to both the other forms was the one thing in the book for which he had given not a demonstrative proof but merely probable reasons. ${ }^{18}$ The undesirability of democratic rule may have been, in Hobbes's view, a matter of opinion rather than certain knowledge; but it was definitely an opinion he held. From a modern perspective, this too must be added to the 'illiberal' side of the argument.

Now let us turn to the other side of Hobbes's political theory: its liberal or proto-liberal elements.

\section{III}

\section{Consent}

Consent is the foundation (in normative or jural terms) of Hobbes's entire political theory. In the human world, it is consent that makes the difference between obedience to authority and acquiescence to mere power-the difference, in effect, between political right and might. In Leviathan he emphasises that consent is what creates and legitimates every political society, either through the covenant that creates a ' $\mathrm{Common}$ wealth by Institution' (a type of covenant described by later writers, using a non-Hobbesian phrase, as a 'social contract'), or through the covenant of obedience that takes place when a person has been defeated in war. At the end of Leviathan, in the 'Review, and Conclusion', Hobbes emphasises once more that the fact of defeat by an enemy power does not in itself create any obligation; only the acceptance of the victor as the new ruler can do that. 'He that is taken, and put into prison, or chaines, is not Conquered ... for he is still an Enemy, and may save himself if hee can: But he that upon promise of Obedience, hath his Life and Liberty allowed him, is then Conquered, and a Subject, and not before. ${ }^{19}$ Exactly what sort of claim Hobbes is trying to make when he sets out his 'social contract' theory - with its simultaneous multilateral covenanting between all the future subjects that, conditionally on all the others doing likewise, each would transfer his or her natural rights to a third-party sovereign - is the subject of never-ending scholarly debate. In broad terms, it seems that he is not trying to sketch some putative factual-historical event; rather, his account is a device for illustrating the nature of the commitment that is implicitly and necessarily present among all the members of a genuine political community - both each member's commitment to his or her fellow members, and the commitment of all

\footnotetext{
${ }^{18}$ Hobbes, 1983, 83.

${ }^{19}$ Leviathan, 391 / iii, 1134.
} 
of them to their ruler. In the case of the covenant of submission to a conqueror, there may well have been a factual-historical event of some sort; but Hobbes's key argument is that the nature of the sovereignty so generated is exactly the same in both cases. ${ }^{20}$

Despite its starting point in psychological naturalism, which has influenced the interpretations of it by many readers, Hobbes's political theory is not naturalistic. It depends on a normative account of rights and duties, arising from the 'artificial' reassignment of people's natural rights - a reassignment that can be made to happen only by those people's own wills. As Hobbes puts it in one of his most fundamental maxims, "there [is] no Obligation on any man, which ariseth not from some Act of his own. ${ }^{21}$ And it is such an obligation, generated by an act of consent, that underlies Hobbes's 'command' theory of law: for 'Law ... [is not] a Command of any man to any man; but only of him, whose Command is addressed to one formerly obliged to obey him. ${ }^{22}$ Much disagreement is of course possible about the real nature of the consent in Hobbes's theory-whether it is tacit, or implicit, or attributed, or some other variety. Some interpretations will have the overall effect of heightening, and others of downgrading, its importance. Yet, from the emphasis placed on it by Hobbes himself, it is clear that it is intended to be more than just one aspect or ingredient among many; he sees it as fundamental to the creation and continued existence of political authority.

To many of Hobbes's royalist friends, this argument about the derivation of authority from consent was shocking. It involved jettisoning almost all the other available justifications of monarchical authority: divine right, biblical precedent, cosmic order, even the rights gained by conquerors in the past (on a non-Hobbesian theory of conquest). Mostly, Hobbes's contemporaries associated consent theory with arguments designed to justify resistance and revolt, thanks to the idea that consent must reasonably contain some built-in conditions.

Hobbes's theory, on the other hand, was unconditional, or at least as unconditional as it could be, subject to the most basic conditions of any political rule (the provision of security and order). So there is good reason for describing it as less 'liberal' than those other versions of consent theory that were available at the time. Yet at the same time we should note that Hobbes's theory was the most philosophically pure and uncompromising. Late scholastic thinkers used the idea of the consent of the community within a framework of natural law theory, and that natural law theory was itself located within a larger teleological framework of what was in accordance with God's design for humanity. In such a system, consent might become quite epiphenomenal, signalling people's approval of a course of action that was in any case

${ }^{20}$ Ibid., 102 / ii, 306.

${ }^{21}$ Ibid., 111 / ii, 336.

${ }^{22}$ Ibid., 137 / ii, 414. 
required of them by natural law. In Hobbes's theory, consent may well have more real work to do.

\section{Natural rights}

The theory of natural rights is another area in which Hobbes develops a concept which has much resonance for later liberal political theories, but uses it in a rather different way. One might say that the reason why consent is so important in the making of the Hobbesian state is precisely that his natural rights are so wide ranging; there is so much that needs to be given up in order to make a stable political society possible. Since Hobbes's natural rights, in the pre-political condition of humanity, allow a huge field of action for the exercise of each individual's will, only a major long-term act of will to surrender or transfer those rights will have the required effect. It is true that modern liberal political theorists have been interested above all in inalienable natural rights - rights which are 'natural' because they inhere in the very nature of human beings, and therefore cannot be separated from them. In this respect, Hobbes differs strongly from the later liberal tradition, as he retains only one inalienable right, the right to seek one's own preservation. But still the fact remains that Hobbes taught people to think in a new way about the foundations of political power, by means of a theory that begins with the rights of the individual, and then uses a mechanism of consent to establish valid rule.

\section{Egalitarianism}

Since Hobbes begins with the rights of each individual, there is a kind of egalitarianism built into his theory from the start. In the construction of the Hobbesian state, it is the consent of each individual that matters; there can be no communal consentgiving, as the sort of communal group that can act as a person does not exist until a prior exercise of consent at the individual level has brought it into being. And every individual's consent must matter as much as every other's.

In theory, such a position could be undermined by natural inequality-if, for instance, rights were a function of abilities, and some people were much more able than others. But Hobbes explicitly dismisses such a view. In chapter 15 of Leviathan he criticises the idea that some are naturally fit to govern and some to be governed, mounting a sardonic attack on Aristotle's concept of the 'natural slave':

I know that Aristotle in the first booke of his Politiques, for a foundation of his doctrine, maketh men by Nature, some more worthy to Command, meaning the wiser sort (such as he thought himselfe to be for his Philosophy;) others to Serve, (meaning 
those that had strong bodies, but were not Philosophers as he;) as if Master and Servant were not introduced by consent of men, but by difference of Wit: which is not only against reason; but also against experience. For there are very few so foolish, that had not rather governe themselves, than be governed by others. ${ }^{23}$

Developing the last point in that passage, Hobbes goes even further: 'If Nature therefore have made men equall, that equalitie is to be acknowledged: or if Nature have made men unequall; yet because men that think themselves equall, will not enter into conditions of Peace, but upon Equall termes, such equalitie must be admitted.' It follows, he writes, that one of the laws of nature is 'That every man acknowledge other for his Equall by Nature. ${ }^{24}$

A hostile critic might say: Hobbes's reason for wishing to reduce everyone to equality is that he wants to make them all equally subject to the sovereign, so that there will be no individuals of enhanced status who could take on the role of defending the rest of the population against the sovereign. Although the principle of equality does its essential work at an earlier, pre-political stage in Hobbes's theory, it is indeed true that, once the state is established, all its citizens are equally subject to the sovereign authority. (That authority, it should be remembered, may take the form of a monarchy, an aristocracy or a democracy; if it is the last of those three, the citizens are all equally subject to a sovereign in which they are, at the same time, all equally participating.) Nevertheless, it would be quite wrong to portray Hobbes's egalitarianism as just a matter of grinding all the citizens' faces equally in the dirt at the sovereign's feet. The purpose of the Hobbesian state is not to grind people down, but to create a framework of order and justice in which people can flourish and pursue their individual ends. There are many passages where he writes with strong moral feeling about the need to curb the arrogance of the mighty, because such a framework of order and justice is threatened by their pretensions and their privileges. Thus, for example, on the equal administration of justice, he explains:

The safety of the People, requireth further, from him, or them that have the Soveraign Power, that Justice be equally administred to all degrees of People; that is, that as well the rich, and mighty, as poor and obscure persons, may be righted of the injuries done them; so as the great may have no greater hope of impunity, when they doe violence, dishonour, or any Injury to the meaner sort, than when one of these, does the like to one of them: For in this consisteth Equity; to which, as being a Precept of the Law of Nature, a Soveraign is as much subject, as any of the meanest of his People. ${ }^{25}$

Reworking this material in the Latin Leviathan, Hobbes adds on the next page a remarkably outspoken passage:

\footnotetext{
${ }^{23}$ Ibid., 77 / ii, 234.

${ }^{24}$ Ibid.

${ }^{25}$ Ibid., 180 / ii, 534
} 
It belongs to the sovereign to see that the common body of citizens are not oppressed by the great ones, and much more that he himself does not oppress them on the great ones' advice ... For the common people are the strength of the commonwealth ... If the great citizens, because they are great, demand reverence on account of their power, why should not the common people be revered, because they are many, and much more powerful? The sedition of the so-called 'Beggars' in Holland should be a warning of how dangerous to the commonwealth it is to despise the ordinary people. The superior status of some citizens has arisen not from some real excellence in them, but from the will of the sovereign ruler, that is, from the will of the commonwealth; so much the less should they affect an uncivil disdain. The common people should not be provoked even by kings; much less by fellow-citizens (however powerful they may be). ${ }^{26}$

Also noteworthy here is Hobbes's comment that the superior status of some people 'has arisen not from some real excellence in them, but from the will of the sovereign ruler, that is, from the will of the commonwealth'. Here we find, quite baldly stated, Hobbes's reductive view of hereditary nobility: the ancestor who was first ennobled was simply the beneficiary of an act of sovereign will, and the fact that his descendant today is granted a continuation of that status is no less dependent on the sovereign power, which permits such inheritance of status to continue just as it permits the observance of customary law. Later in the same chapter, Hobbes goes out of his way to state that there is no connection between such special status and intrinsic abilities. Discussing the sovereign's need for good counsellors, he writes: 'Good Counsell comes not by Lot, nor by Inheritance; and therefore there is no more reason to expect good Advice from the rich, or noble, in matters of State, than in delineating the dimensions of a fortresse. ${ }^{27}$

For Hobbes, to say that noble status is a function of the sovereign's will is at the same time to validate that status as strongly as possible. His moral injunction is against the abuse of higher status, not against its existence as such; he is not a leveller. But he does emphasise that 'As in the presence of the Master, the Servants are equall, and without any honour at all; So are the Subjects, in the presence of the Soveraign. And though they shine some more, some lesse, when they are out of his sight; yet in his presence, they shine no more than the Starres in presence of the Sun. ${ }^{92}$ The fact that the sovereign can make and unmake inequality means that we, the subjects, are,

\footnotetext{
${ }^{26}$ Ibid., ii, 536 (n.), 537 ('Ejusdem est videre, ne vulgus Civium à Magnatibus opprimatur, multo magis ne eorum consilio ipse opprimat ... Sunt enim Civitatis robur homines plebeji ... Si Cives magni quia magni propter potentiam coli postulant, Quidni \& plebs quia multi, \& potentior multo coli debeat. Quam autem Civium modicorum vilipendium Civitati periculosum est seditio eorum in Batavia, quae Mendicorum dicta est, monere debet. Civium inaequalitas non à re aliqua in seipsis eximia, sed à voluntate Summi Imperantis profecta est, id est à voluntate Civitatis; tantoque minus, facere debent fastum incivilem. Irritandum vulgus, ne à Regibus quidem est; multo minus à concivibus quantuncunque sint potentes'). ${ }^{27}$ Ibid., 184 / ii, 546.

${ }^{28}$ Ibid., 93 / ii, 280.
} 
vis-à-vis the sovereign, all essentially equal. One might call this Hobbes's 'absolutist egalitarianism' - a position in which his 'illiberal' absolutism and 'liberal'egalitarianism are perfectly combined.

This leads to another important proto-liberal theme:

\section{The state as a device to protect people against oppression}

Some readers of Hobbes may find this a surprising angle to take on his political theory. Surely, they will argue, the main problem is that a Hobbesian state will itself oppress the people. Whenever students are introduced to Leviathan, that is the largest and most troubling question that quickly occurs to them: how will it be possible to defend the subjects against the power of Hobbes's 'absolute' sovereign? The question is certainly a valid one, but it prevents them from seeing how important it is, for Hobbes, that the sovereign should have enough power to protect his, her or its own subjects from potential oppressors within the state (as well as from those outside it). The central point here - that one of the vital roles of state power is to protect individual citizens from oppressive groups, institutions, or individuals inside the state itself - is, I believe, an important part of the modern liberal political tradition. Oppressors can take many forms: feudal landlords; religious organisations; the institution of slavery; coercive sexual relations in the family; and so on. As the great liberal reform programmes of the 19th and 20th centuries show, it is the state and only the state that has the necessary power to protect people against these oppressive forces, the power to change or remove their power.

This liberal justification for state power is sometimes rather neglected by modern theorists, who concentrate instead on the question of how that power can best be controlled and restrained. One recent exception is Brian Barry, whose book Culture and Equality sets out the liberal case for the use of the state's authority to limit the power of groups over their members: groups may function freely as voluntary associations, he argues, but they may not inflict any harm on their own members of the kind that would be forbidden between any two members of society generally. ${ }^{29}$ Thus a liberal state can accept the Roman Catholic Church (in its modern form), but not the Spanish Inquisition. Hobbes, despite his fierce hostility to Catholicism, does allow that the Roman Church can operate within a state, at least as a teaching and preaching ministry, if the sovereign permits it to do so. What he does not accept is that any Church, Catholic or Protestant, may seek to control people through a power structure of its own - either the formal structure of the ecclesiastical courts, or the psychological

\footnotetext{
${ }^{29}$ Barry (2001).
} 
pressure of 'the Fear that Seduced people stand in, of their Excommunications' ${ }^{30}$ Of course, Hobbes's most pressing concern is that such power structures, if left unchecked, may threaten the sovereign's own power. But his fiercely satirical description of the Roman Catholic Church as a 'Kingdome of Fairies' in the last part of Leviathan does also have an unmistakable moral charge, in its portrayal of ordinary lay people suffering from psychological manipulation and financial exploitation. ${ }^{31}$ Hobbes's earlier injunctions against permitting the 'mighty' to oppress people with impunity are no less relevant here, as he depicts a mighty institution inflicting harm in ways that are protected by legal immunity and social privilege.

From this theme, the next follows quite closely:

\section{The homogeneity of all legal authority in the state}

It would probably be wrong to say that this principle is intrinsic to modern liberal political theory, as some versions of liberal pluralism may be content to accept a plurality of legal authorities within any particular political society. But the classic modern idea of a Rechtsstaat does presuppose a reliable consistency in the whole body of legal rights and duties that governs both the agents of the state and its subjects; and the notion of equal treatment under the law does seem to require a coherent and, so to speak, solid legal framework, not an overlapping arrangement of different legal authorities that can be applied or appealed to on different bases.

As we have seen, Hobbes does accept that there may be agencies or subordinate authorities of various kinds within the state. The existence of dukes and barons, who may exercise some local legal authority, is unproblematic, so long as it is understood that all their powers flow from the sovereign. Even Hobbes's hated Roman Catholic Church can operate (with at least, we may reasonably assume, some disciplinary powers over its own clergy), so long as it does so on sufferance, by the sovereign's permission. Hobbes does not argue for a state in which one finds a sovereign on the one hand and an undifferentiated mass of subjects, all reduced to one level of social or organisational life, on the other. He is no enemy of civil society; on the contrary, he devotes pages of Leviathan to describing many kinds of intermediate institutions in the state - what he calls 'systems', or corporate bodies, both public and private. ${ }^{32}$ What he does argue is that, insofar as they exercise any authority, they do so by the sovereign's permission, which means that their authority is a form or subset of the sovereign's

\footnotetext{
${ }^{30}$ Leviathan, 387 / iii, 1122.

${ }^{31}$ Ibid., 386-7 / iii, 1118-22.

${ }^{32}$ Ibid., 115-23 / ii, 348-74.
} 
own authority. It may be exercised independently in practice, but in the final analysis it has no independent politico-legal standing.

As Hobbes explains, 'the Magistrates of Towns, Judges in Courts of Justice, and Commanders of Armies, are all but Ministers of him that is the Magistrate of the whole Common-wealth, Judge of all Causes, and Commander of the whole Militia, which is alwaies the Civill Soveraign.' ${ }^{33}$ The point may seem obvious in those cases, where the 'ministers' are all appointed from above. But Hobbes emphasises that it applies equally to those figures of authority within the state who are appointed or elected from below: 'when a Town choose their Maior, it is the act of him that hath the Soveraign Power: For every act done, is the act of him, without whose consent it is invalid. ${ }^{34}$ Here too the argument presupposes that there can be no independent locus of authority within the state. Once again, the case resembles that of customary law: what gives that law authority is not the fact that it has been observed for hundreds of years in the past, but rather the fact that at the present time the sovereign, who could declare it invalid, forbears to do so. ${ }^{35}$ And, just as the voters in a mayoral election, using their own discretion to choose among the candidates, are acting by the authority of the sovereign, so too every state official, using his or her discretion to make an administrative decision, is acting by that authority: so long as the decision-making lies within the official's legal powers, and the correct procedures are followed, that decision is to be regarded as the sovereign's own decision. It is on such a basis that a Rechtsstaat is founded.

The unyielding clarity of Hobbes's argument here - which, we should note, forms part and parcel of his 'absolutist' understanding of sovereign authority-made him something of a pioneer. There were many who were happy to accept the heterogeneity of authority, whether legal or, indeed, political — that is, the idea that within the state there may be groups or institutions whose authority is either separately derived, or intrinsic to them. Some versions of this position have been celebrated as harbingers of modern constitutionalism: for example, the resistance theory developed by Calvinists in the late 16th century, in which 'inferior magistrates' could exercise an independent authority vis-à-vis the monarch, or the so-called 'thèse nobiliaire' of Louis XIV's critics in the late 17 th and early 18 th centuries, which attributed an intrinsic authority to the hereditary nobility as a counterweight to the king. In such cases, the positive implications for a kind of constitutionalism may be easier to grasp than the negative ones for the development of the concept of a general rule of law; nevertheless, those negative implications deserve to be considered.

\footnotetext{
${ }^{33}$ Ibid., 295 / iii, 852.

${ }^{34}$ Ibid.

${ }^{35}$ Ibid., 138 / ii, 416: 'When long Use obtaineth the authority of a Law, it is not the Length of Time that maketh the Authority, but the Will of the Soveraign signified by his silence, (for Silence is sometimes an argument of Consent;).'
} 


\section{The concept of the state as the public realm}

One of the most important elements in Hobbes's theory that can be seen as a precursor or building-block for a modern liberal theory of the state is his conception of the state as a public realm. This idea is, arguably, essential for any modern theory of citizenship; without it, the state will be something like a patrimonial possession, or a device for the benefit of an interest-group. Of course, Hobbes did not invent this out of nothing; the notion that a corporate body can have a kind of 'personality' in law, for example, had a long previous history. But Hobbes gave a new, unusually rich and suggestive account of the personhood of the state, and placed it at the heart of his theory. ${ }^{36}$ To summarise very briefly: according to Hobbes, the sovereign (whether monarch, aristocratic assembly, or democratic assembly) represents the people - that is, the people as an entity, not the 'multitude' or mere aggregate of individuals. And the people exists as an entity only by virtue of being represented. The sovereign 'bears the person' of the people; so, while the sovereign is a natural person or a set of natural persons, and the subjects or citizens are natural persons, there is a more theoretical person that somehow hovers in between them, making the multitude a people and making the flesh-and-blood royal human being (or flesh-and-blood assembly members) a sovereign authority. That is the person of the state: without it, both the subjects and the ruler would be just private individuals, but with it, there is a realm of the public, which constitutes them both, endowing them with political meaning and identity.

When one reads Leviathan, it is worth pausing for thought every time one sees the word 'public'. The executive power of the sovereign is 'the publique Sword'; the sovereign acts for 'the publique peace', 'the publique good', 'the publique interest', 'the Publique quiet', and 'the Publique Tranquillity'; and the sovereign defends 'the Publique Liberty' against foreign enemies. ${ }^{37}$ These adjectival uses, at least, seem straightforward. But what about the use of the word as a noun? When people complain about taxation, they say they are 'grieved with payments to the Publique'. Troublesome subjects 'thinke themselves wiser, and able to govern the Publique, better than the rest'. A sovereign assembly may delegate to another body the power of electing people to its own ranks, but can always recall that power 'when the publique shall require it'. People make false claims about civic liberty when they treat it as a 'Private Inheritance', given that it is in fact 'the right of the Publique only'. Gatherings of private individuals for undisclosed purposes should be regarded as 'dangerous to the Publique'. Embezzling state funds is worse than stealing from an individual, 'because to robbe the publique, is to robbe many at once'. The most severe punishments should be inflicted 'for those Crimes, that are of most Danger to the Publique'. And finally, as

\footnotetext{
${ }^{36}$ See the classic study by Quentin Skinner (2002).

${ }^{37}$ Leviathan, 89 / ii, 268; 91 / ii, 274; 92 / ii, 274; 96 / ii, 288; 380 / iii, 1102; 395 / iii, 1140; 395 / iii, 1141.
} 
Hobbes explains, 'by Publique, is alwaies meant, either the Person of the Commonwealth it self, or something that is so the Common-wealths, as no private person can claim any propriety therein. ${ }^{38}$ The resemblance to modern phraseology can thus be rather misleading; whereas today we would take 'crimes that are of danger to the public' to refer to acting in certain ways in public places, or through media that can reach many among the population, Hobbes refers to a reified 'public' which is more like the 'res publica' of Roman political discourse - the 'public affair' or 'public good'. The standard English equivalent of 'res publica', in Hobbes's day, was 'commonwealth'; and in the majority of the passages just cited, the translation of 'the Publique' given in Hobbes's Latin version is 'civitas', the directly equivalent term for 'the Common-wealth' in his political theory.

How, then, can this emphasis on the public realm be squared with Hobbes's passionate insistence that monarchy is the best form of government? The answer has already been touched on above: Hobbes believes that assemblies, especially democratic ones, will become the means for individuals, or groups of like-minded individuals, to pursue their own private interests. The contrast between 'public' and 'private' runs through Hobbes's entire argument: the public sword defends the state, while the private sword destabilises it; private interest corrupts the state, and/or makes people rebel. As a general rule, each natural person does of course seek his own individual interest, and 'for the most part, if the publique interest chance to crosse the private, he preferrs the private.' The somewhat bold claim that Hobbes makes is that 'in Monarchy, the private interest is the same with the publique', for the simple reason that 'The riches, power, and honour of a Monarch arise onely from the riches, strength and reputation of his Subjects.' Whereas, he argues, 'in a Democracy, or Aristocracy, the publique prosperity conferres not so much to the private fortune of one that is corrupt, or ambitious, as doth many times a perfidious advice, a treacherous action, or a Civill warre. ${ }^{39}$ Whilst readers may well feel that the problem of short-sighted rapacity in monarchs is passed over too lightly here, they should take note of the fact that the promotion of the public good is presented by Hobbes not as something that just happens to be compatible with monarchy, but rather as a fundamental normative reason why monarchy is to be preferred.

Another important aspect of Hobbes's theory flows directly from this concept of the public:

${ }^{38}$ Ibid., 50 / ii, 160; 87 / ii, 258; 99 / ii, 300; 110 / ii, 334; 122 / ii, 370; 160 / ii, 478; 182 / ii, 542; 220 / iii, 646.

${ }^{39}$ Ibid., 96 / ii, 288. 


\section{The sovereign acts publicly—above all, through law}

The sovereign was set up for a general, public purpose: 'the publique peace', the public good. And because he, she, or it relates to particular citizens not on an individual-to-individual basis, but as the bearer of the public 'person' of the commonwealth, in which all citizens are equally represented, the sovereign acts in 'public' ways - most importantly, through law. That laws have an essentially public character is something heavily emphasised in Hobbes's account. Every law, he insists, must be 'written, and published', and there must be 'manifest signs, that it proceedeth from the will of the Soveraign'. ${ }^{40}$ Those signs must be obtainable by consulting 'publique Registers, publique Counsels, publique Ministers, and publique Seales'. ${ }^{41}$ The word 'publique' here has Hobbes's general meaning of pertaining to the public realm of the state, but it also contains the concept of that which is publicly declared or publicly knowable; and it is on that basis that Hobbes insists that laws must be prospective, not retrospective. 'No Law, made after a Fact done, can make it a Crime: because ... a Positive Law cannot be taken notice of, before it be made. ${ }^{42}$

Just as importantly, Hobbes stresses that it is in the nature of law to be general. In his late dialogue-work Behemoth he includes a discussion of an imaginary case in which a tyrant commands a subject to be the executioner of his (the subject's) own father, when that father has been convicted and condemned to death. The question is put: would the subject be entitled to disobey such a command? The speaker who represents Hobbes comments that by disobeying the king 'we mean the disobeying of his Laws, those his Laws that were made before they were applyed to any particular person. For the King ... commands the people in generall neuer but by a precedent Law, and as a Politick not a Naturall person. ${ }^{43}$ So the answer is that the subject would be bound to obey that command only if it had been a properly made and pre-existent general law. Were it just an ad hoc command, on the other hand, the subject would have the right to disobey. (The reasoning here being not that all subjects can automatically disregard all ad hoc commands, but rather that the general condition of obedience to public laws is something fundamental that they must have consented to in agreeing to be a member of the political community. Obedience to the sovereign's commands is a requirement, but a defeasible one in special circumstances, whereas that of obedience to law is indefeasible.)

Hobbes also emphasises that all laws require interpretation when they are applied to particular facts. And since this is done by judges who exercise the sovereign's authority, law has a 'public' quality at this level too: the judge's reasoning must rest on

\footnotetext{
${ }^{40}$ Ibid., 141 / ii, 426.

${ }^{41}$ Ibid., 142 / ii, 426.

${ }^{42}$ Ibid., 153 / ii, 458.

${ }^{43}$ Hobbes (2010: 174).
} 
principles that are general, not on preferences of a private kind. 'The Judge is to take notice, that his Sentence ought to be according to the reason of his Soveraign, which being alwaies understood to be Equity, he is bound to it by the Law of Nature. ${ }^{44}$ The phrase 'the reason of his Soveraign' here refers to the sovereign as a public person, not the natural person or persons occupying the sovereign office. In the Latin Leviathan Hobbes writes at this point that 'the state is understood to wish equity to its citizens', and later in the same chapter he explains: 'But how can one know what the legislator wished to be understood by the words of a law? It is known from the fact that the legislator (that is, the person of the commonwealth) must always be understood to wish that which is equitable. ${ }^{45}$

An interesting recent movement in Hobbes scholarship, building on such passages as the one quoted from Behemoth above, has suggested that Hobbes's sovereign can act only through law. The argument here is that an action can be identified as expressing the will of the sovereign - not the flesh-and-blood person or persons, but the sovereign qua bearer of the 'artificial person' of the state - only if it meets certain general and publicly recognisable criteria; therefore 'all acts of sovereignty must comply with the law to be recognisable as acts of sovereignty. ${ }^{46}$ And a further claim, developed as part of the same argument and drawing on passages such as the one just quoted about the recourse of judges to equity in interpreting the sovereign's will, is that there are natural law duties, such as the need for equity, which amount to substantive requirements as to what the contents of the sovereign's laws must be. ${ }^{47}$

The first of these claims may seem, at first sight, the more challenging to traditional interpretations of Hobbes. Yet the point it makes is essentially an analytic one, which should not be difficult to accept. Hobbes clearly allows that a sovereign, acting in his, her, or its sovereign capacity, can issue commands that are ad hoc or indeed ad hominem: he notes that King David (as commander-in-chief of the army) issued the order that brought about the death of Uriah the Hittite, and that the Athenian people, exercising its power as a sovereign democracy, voted by ostracism to expel individuals from its state. ${ }^{48}$ The analytic point is simply that there was some pre-existing framework of law that made an order of the commander-in-chief, or a vote of ostracism, a recognisably valid act. No sovereign, in Hobbes's theory, is forever trapped or constrained by the particular framework in which it operates, as the power to alter that

\footnotetext{
${ }^{44}$ Leviathan, 141 / ii, 424.

${ }^{45}$ Ibid., ii, 425 ('Civitas ... Civibus Aequum velle intelligitur'), 437 ('Legislator autem, quid per verba Legis intelligi voluit, unde cogno? Ex eo cognoscitur, quod Legislator, (id est Persona Civitatis) semper intelligendus est velle id, quod aequum est').

${ }^{46}$ Dyzenhaus (2012: 198(n.)).

${ }^{47}$ Ibid., 199; Fox-Decent (2012).

${ }^{48}$ Leviathan, $109-10$ / ii, 330.
} 
framework belongs to sovereignty itself; the point is merely that the process of alteration must also be a recognisably sovereign act, proceeding from public authority. In this sense it is possible to agree that there is a public and general dimension to everything the sovereign does, without arguing that there are any permanent constraints on what the sovereign can do. ${ }^{49}$

The second claim, however, does posit such constraints: it implies that an inequitable or bad law is not really a law at all. And that surely is a claim too far, given the whole structure of Hobbes's theory, which allows him to distinguish quite clearly between laws which are good and laws which — while still being valid laws - are bad. He does say that 'the making of Good Lawes' belongs to the 'office' or duty of the sovereign; but in cases where a sovereign fails to perform that duty, he, she, or it will still be a legislator. When Hobbes writes that 'a Law that is not Needfull, having not the true End of a Law, is not Good', and that 'Unnecessary Lawes are not good Lawes; but trapps for Mony', he does not suggest that subjects are under no obligation to obey such laws. ${ }^{50}$ And as for acts of the sovereign being invalidated if they fail to conform with equity, we have Hobbes's explicit assurance to the contrary: 'It is true that they that have Soveraigne power, may commit Iniquity; but not Injustice, or Injury in the proper signification. ${ }^{51}$ It is hard to imagine anything more iniquitous than a general law decreeing that sons must execute their condemned fathers; yet Hobbes says that were such a general law enacted, no subject would have the right to disobey it.

Hobbes's concept of law is not as liberal, then, as some might wish. Nevertheless, he does place law-making at or near the heart of his account of political authority, and he does have a clear concept of the public and systematic character of the law. This is not the caricature defender of 'despotism'; it is someone who stands within the mainstream development of the idea of a rule of law. We just have to bear in mind that for Hobbes, the phrase 'rule of law' would not mean rule by the law as opposed

\footnotetext{
${ }^{49}$ One apparent obstacle to this argument — as Dyzenhaus notes (2012: 198(n.)) - is the passage in Leviathan where Hobbes distinguishes between a sovereign demanding money, goods, or services from a subject on the basis of 'a precedent Law', and doing so 'by vertue of his Power' (sc. as the Latin makes clear, his sovereignty: 'virtute Potestatis Summae'): Leviathan, 113 / ii, 342-3. The problem might be resolved by making a distinction between laws in a narrow sense and politico-legal norms of a more general kind. In Hobbes's theory it is an implicit norm in every state - implied by the original covenantthat the sovereign may take whatever action he, she, or it judges necessary for the people's preservation. Presumably it is action of that kind that Hobbes envisages here.

${ }^{50}$ Leviathan, 181-2 / ii, 540.

${ }^{51}$ Ibid., 90 / ii, 270. Hobbes confirms this in the equivalent passage of the Latin Leviathan (ii, 270(n.), 271): 'I have not denied that the sovereign can act iniquitously [or: 'inequitably']. For that which is done against the law of nature is called 'iniquitous', and that which is done against the civil law is called 'unjust' ('Quin is qui Summam habet Potestatem facere iniquè possit, non negaverim. Iniquum enim quod contra Legem Naturae, Injustum quod contra Legem Civilem factum est, appellatur').
} 
to by the sovereign. It would mean that the sovereign rules through law: the political realm acts through the legal realm.

Which brings us back to:

\section{The problem of constitutionalism}

Hobbes was described above as anti-constitutionalist, where theories of 'mixed monarchy' or 'limited monarchy' were concerned. His analytic argument is unyielding: it is a necessary truth that in every state there is an ultimate holder of authority, which must be either one human being, or several, or many. Nevertheless, at the descriptive level there is room for considerable flexibility, for Hobbes borrows from Jean Bodin the distinction between the sovereign and the administration or government. ${ }^{52}$ Sovereigns can delegate, committing the exercise of particular powers to other individuals or bodies of people: 'though the sovereignty be not mixed, but be always either simple democracy, or simple aristocracy, or pure monarchy; nevertheless in the administration thereof, all those sorts of government may have place subordinate.' The examples Hobbes gives include the Roman Republic, which had a democratic sovereign, granting powers to an aristocratic council (the Senate), or even setting up what he calls 'a subordinate monarch' (the Roman 'dictator'), who could exercise sovereign power for a limited period. ${ }^{53}$ That the House of Lords and the elected House of Commons have a genuine role in the exercise of the sovereign power of legislation is, therefore, something that Hobbes's theory can easily accommodate. In De cive he even suggests that, if a democracy were to hand over the task of deliberating legislation, and war and peace, to one man or a very small group of men (thus eliminating the problem of oratorical faction-mongering in big assemblies), it could function just as well as a monarchy in those areas - a remarkable concession, from someone so generally hostile to democracy itself. ${ }^{54}$

Hobbes emphasises the difference between a sovereign handing over a particular power to another person or body, and committing it in a fiduciary way to be exercised in the sovereign's name: 'He that Transferreth his power, hath deprived himself of it, but he that Committeth it to another to be Exercised in his name, and under him, is still in the Possession of the same power. ${ }^{55}$ Minor powers, such as the power to mint money, can be given to others; but the essential powers of sovereignty-control over legislation, justice, the armed forces, etc. - cannot be handed over. ${ }^{56}$ They can be

\footnotetext{
${ }^{52}$ Cf. Bodin (1962: 199-200, 249).

${ }^{53}$ Hobbes, 1889, II.i.17, 115-16 (and on the dictator cf. Bodin 1962: 86).

${ }^{54}$ Hobbes, 1983, X.15, 179.

${ }^{55}$ Hobbes, 2005, 54-5.

${ }^{56}$ Leviathan, 92-3 / ii, 278.
} 
exercised in various ways by others within the state, but in some sense the highest or purest form of the power is still exercised by the sovereign - who, for example, while leaving the conduct of war to the army high command, still exercises the power to appoint or dismiss the generals.

Overall, then, there is much room in Hobbes's theory for the modification of direct rule: structures of government can be developed, legal and political institutions can be set up, and the exercise of sovereign powers can be distributed to agencies of different kinds. He does not engage in the sort of constitution-designing that tries to set up checks and balances; whilst he would have no difficulty with the idea that a prudent sovereign might wish to limit and counterbalance the powers of particular elements of the administration, he would reject the notion that the will of the sovereign should be checked or counterbalanced in any way. As we have seen, Hobbes could not accept the idea that a constitution can be a higher authority, on which the sovereign authority itself is dependent. Nevertheless, within these limitations, it is possible to say that his political theory is perfectly compatible with a kind of descriptive constitutionalism that can investigate the structures and processes of different governments, and find some more effective and beneficial than others.

Hobbes's insistence that men rule, not laws, often strikes modern political theorists as naïve: they wish to point out that in every state there are some fundamental laws or principles which function as preconditions for the exercise of rule by human beings. ${ }^{57}$ But I think it is possible to say that Hobbes did understand this aspect of political existence; the point is merely that he did not conceptualise it as being ruled by a law. That his concept of the sovereign as a public person, which acts in public ways, complies with a basic 'rule of recognition' (the fundamental law in all legal systems, according to H. L. A. Hart) has already been suggested above. But there are other fundamental principles in Hobbes's theory which relate directly to the exercise of sovereign power; one might even call them constitutional principles, so long as this were not taken to imply the placing of sovereignty under a constitution's superior authority.

The clearest example of this comes in the discussion of the original covenant in $D e$ cive. Hobbes explains that if people meet to create a state, they are presumed to agree to a majority decision-making principle; that meeting is therefore a democracy so long as it lasts, but the democracy will cease to exist when they break up their meeting unless the time and place of the next meeting are 'publicly known and determined'. Then, if they decide to become a proper democratic sovereign state, they must not only have an agreed schedule of meetings, but also agree to 'grant the use' of the sovereign power to some individual or committee in the intervening periods between their

\footnotetext{
${ }^{57}$ See, for example, Hampton (1995), which criticises Hobbes on this basis, citing H. L. A. Hart and Hans Kelsen.
} 
general meetings. ${ }^{58}$ So, in the space of just a few sentences, Hobbes has set out three constitutional principles that are essential for the functioning of a democracy: majority voting; regular (or, at least, predetermined) meetings of the sovereign assembly; and the exercise of power by ministers in the interim. It seems reasonable to say that he would think of these not as superior constraints placed over the democratic sovereign, but rather as necessary implications of any covenant to submit to democratic rule: insofar as people consented to democracy, they must have consented to this.

In the case of monarchy, it is at first sight much less clear what could count as an equivalent constitutional principle; certainly, none of those three democratic principles would apply. But consider the problem of succession to monarchical rule - an issue to which Hobbes pays some particular attention in Leviathan. ${ }^{59}$ When the king is a small child, his sovereign powers are exercised in his name by ministers. This arrangement will normally have been designated by the previous king or queen, who did rule directly. But when we obey the laws or commands of this infant king, whom or what are we actually obeying? The ministers? Only insofar as they act on behalf of their infant monarch; yet he gives them no orders. Or are we, rather, obeying the command of the previous sovereign? To answer 'yes' to that question might seem to be the simple solution, by analogy with what we do when we honour the wishes expressed in a deceased person's testament. But the honouring of testaments takes place within the normal framework of the state; is a duty specified by the legal system, which is itself to be obeyed because it is the law of the sovereign. If we accept the analogy here, we must say that the reason why we now obey the command of the previous sovereign (which decreed that we should take these ministers' orders as representing the will of the infant sovereign) is that the infant sovereign now wills us to obey, in this matter, the command of the previous sovereign; and yet the starting point of the problem was that we cannot know what the will of the infant sovereign is, other than the will imputed to him by his ministers.

Hobbes does not give an explicit solution to this dilemma. Nevertheless, an answer can be suggested which is in keeping with his larger pattern of argument: when we obey the ministers as representatives of the infant king, we are following a constitutional principle of monarchy - an underlying rule as basic to it as the three rules outlined above are to democracy. Here too, it seems, Hobbes would not say that we- or, still less, the infant king, or his ministers - were being ruled by a constitution. Rather, he would say that we are acting in accordance with the basic terms of our political covenant, the covenant which exists between each subject and every other subject in a monarchical system of rule, forming the web of mutual commitments that binds them

\footnotetext{
${ }^{58}$ Hobbes, 1983, VII.5-6, 152-3 ('cognitus \& constitutus palam'; 'vsum ... concedant').

${ }^{59}$ Leviathan, 97 / ii, 292-4.
} 
together and relates them to their ruler in a single political community. That is the very foundation of Hobbes's theory - a theory rich in possible implications for modern political thought, and very different from any simple apologia for despotic rule.

\section{REFERENCES}

Arendt, H. (1973), The Origins of Totalitarianism, revised edn (New York, Houghton Mifflin Harcourt). Barry, B. (2001), Culture and Equality: An Egalitarian Critique of Multiculturalism (Cambridge, Polity).

Bodin, J. (1962), The Six Bookes of a Commonweale, trans. R. Knolles, ed. K. D. McRae, (Cambridge, MA, Harvard University Press). http://dx.doi.org/10.4159/harvard.9780674733169

Carr, E. H. (1939), The Twenty Years' Crisis, 1919-1939: An Introduction to the Study of International Relations (London, Macmillan).

Degryse, A. (2008), 'The Sovereign and the Social: Arendt's Understanding of Hobbes', Ethical Perspectives, 15: 239-58. http://dx.doi.org/10.2143/EP.15.2.2032369

Dyzenhaus, D. (2012), 'Hobbes on the Authority of Law', in D. Dyzenhaus \& T. Poole (eds), Hobbes and the Law (Cambridge, Cambridge University Press), 186-209.

http://dx.doi.org/10.1017/cbo9781139137034.010

Fox-Decent, E. (2012), 'Hobbes's Relational Theory: Beneath Power and Consent', in D. Dyzenhaus \& T. Poole (eds), Hobbes and the Law (Cambridge, Cambridge University Press), 118-144. http://dx.doi.org/10.1017/CBO9781139137034.007

Hampton, J. (1995), 'Democracy and the Rule of Law', in I. Shapiro (ed.), Nomos XXXVI: The Rule of Law (New York, New York University Press), 13-44.

Hobbes, T. (1889), The Elements of Law, Natural and Politic, F. Tönnies (ed.), (London, Simpkin, Marshall).

Hobbes, T. (1983), De cive: The Latin Version, H. Warrender (ed.), (Oxford, Clarendon Press).

Hobbes, T. (2005), Writings on Common Law and Hereditary Right, A. Cromartie \& Q. Skinner (eds), (Oxford, Clarendon Press).

Hobbes, T. (2010), Behemoth or the Long Parliament, P. Seaward (ed.) (Oxford, Clarendon Press).

Hobbes, T. (2012) Leviathan, N. Malcolm (ed.) 3 vols, (Oxford, Clarendon Press). http://dx.doi.org/10.1093/oseo/instance.00025178

Hoekstra, K. (2006), 'A Lion in the House: Hobbes and Democracy', in A. Brett, J. Tully \& H. HamiltonBleakley (eds), Rethinking the Foundations of Modern Political Thought (Cambridge, Cambridge University Press), 191-218. http://dx.doi.org/10.1017/cbo9780511618376.012

Kaufman, W, A. (1950), Nietzsche: Philosopher, Psychologist. Antichrist (Princeton, NJ, Princeton University Press).

Mayer-Tasch, P. C. (1965), Thomas Hobbes und das Widerstandsrecht (Tübingen, Walter De Gruyter).

Mendle, M. (1985), Dangerous Positions: Mixed Government, the Estates of the Realm, and the Answer to the XIX Propositions (University, AL, University of Alabama Press).

Morgenthau, H. (1955), Politics among Nations: The Struggle for Power and Peace, 2nd edn (New York, Knopf).

Skinner, Q. (2002), 'Hobbes and the Purely Artificial Person of the State', in his Visions of Politics, 3 vols, (Cambridge, Cambridge University Press), iii, 177-208.

http://dx.doi.org/10.1017/cbo9780511613784.009

Sreedhar, S. (2010), Hobbes on Resistance: Defying the Leviathan (Cambridge, Cambridge University Press). http://dx.doi.org/10.1017/CBO9780511762376

Wolin, S. S. (1990), 'Hobbes and the Culture of Despotism', in M. G. Dietz (ed.), Thomas Hobbes and 
Political Theory (Lawrence, KS, University Press of Kansas), 9-36

Note on the author: Sir Noel Malcolm FBA is a Senior Research Fellow at All Souls College, Oxford. He is a General Editor of the Clarendon Edition of the Works of Thomas Hobbes, and has edited Hobbes's Correspondence (2 vols, Oxford, Clarendon Press, 1994) and the English and Latin texts of Leviathan (3 vols, Oxford, Oxford University Press, 2012) for that edition. His most recent book is Agents of Empire: Knights, Corsairs, Jesuits and Spies in the Sixteenth-century Mediterranean World (London, Allen Lane, 2015).

noel.malcolm@all-souls.ox.ac.uk

To cite the article: Noel Malcolm (2016), 'Thomas Hobbes: Liberal illiberal', Journal of the British Academy, 4: 113-136.

DOI $10.85871 / \mathrm{jba} / 004.113$

This article is licensed under a

Creative Commons Attribution-NonCommercial-NoDerivs 3.0 Unported License.

Journal of the British Academy (ISSN 2052-7217) is published by

The British Academy - the national academy for the humanities and social sciences. 10-11 Carlton House Terrace, London, SW1Y 5AH

www.britishacademy.ac.uk 